\title{
KAJIAN CITRA KOTA DALAM BRANDING CITY BEAUTIFUL MALANG.
}

\author{
Josaf Sayoko dan Respati Wikantiyoso* \\ Magister Arsitektur, Program Pascasarjana, Universitas Merdeka Malang \\ *respati@unmer.ac.id
}

\begin{abstract}
ABSTRAK
Keindahan fisik kota merupakan kondisi, karakter, citra yang terbentuk dari setting lingkungan binaan dan lingkungan alamiahnya. Upaya membuat City Branding dengan mengangkat tema Beautiful Malang menjadi relevan apabila diikuti dengan upaya-upaya pemerintah kota untuk menjaga "keindahan lingkungan buatan dan alamiahnya" dalam kebijakan pengembangan kota Malang. Upaya pemerintah Kota Malang menggunakan City Branding "Malang Beautiful" dilakukan untuk memperkuat image kota Malang sebagai kota untuk tujuan wisata lingkungan binaan. Pembahasan tentang persepsi keindahan suatu kota tidak terlepas dari permasalahan image dari pengguna kota.Dengan demikian pembahasan beautiful Malang sebagai branding, maka tidak akan terlepas dari pemahaman Image suatu kota/ kawasan. Pemahaman image sebuah kota mencakup 5 elemen, yakni Path, Edge, District, Nodes, dan Landmark. Tulisan ini bertujuan mengkaji City Branding Beautiful Malang ditinjau dari teori Citra kota yang dikemukakan oleh Kevin Lynch dalam bukunya " Image of The City".
\end{abstract}

Keywords: Branding City, Citra Kota, Malang Beautiful

\begin{abstract}
The physical beauty of a city is a condition, character, image formed from the setting of the built environment and its natural environment. The effort to make City Branding by raising the theme Beautiful Malang becomes relevant if it is followed by the efforts of the city government to maintain the "beauty of the artificial and natural environment" in the policy of developing the city of Malang. The efforts of the Malang City government to use the City Branding "Malang Beautiful" were carried out to strengthen the image of Malang City as a city for the fostered environment tourism destination. The discussion about the perception of the beauty of a city is inseparable from the image problem of the city users. Thus, the discussion of beautiful Malang as a branding, it will not be separated from the understanding of the image of a city / region. Understanding the image of a city includes 5 elements, namely Path, Edge, District, Nodes, and Landmarks. This paper aims to examine the City Branding Beautiful Malang in terms of the theory of the city image proposed by Kevin Lynch in his book "Image of The City". Keywords: City Branding, Image of the City, Malang Beautiful
\end{abstract}




\section{PENDAHULUAN}

Kota Malang merupakan salah satu kota yang sebagian besar bagian kotanya dirancang dengan baik pada masa Kolonial Belanda. Konsep rancang kota yang diterapkan sangat memperhatikan potensi lingkungan alamiah dengan keberadaan "putri tidur" di sisi barat kota Malang (Wikantiyoso, 2005). Kondisi alamiah yang dikelilingi bukit, menjadikan kota malang memiliki iklim yang sejuk dan relatif subur. Dengan potensi alamiah, lingkungan binaan serta budaya kota Malang, maka Kota Malang menjadi daerah tujuan wisata. Pengembangan Malang menjadi wilayah Malang Raya (kota Malang, Kabupaten Malang dan Kota Batu) telah menggeser posisi pariwisata kota Malang menjadi pariwisata lingkungan binaan dengan Meeting, Incentive, Conference, and Exhibition (MICE).

Berbagai upaya dilakukan oleh pemerintah kota Malang untuk tetap mendudukkan kota Malang sebagai destinasi wisata unggulan. Berbagai julukan Malang sebagai kota wisata mulai dengan brand Malang sebagai Kota Apel (sekarang milik kota Batu dan Poncokusumo), Malang Kota Bunga (MAKOBU), Malang Asoy, Welcoming Malang, sampai dengan Beautiful Malang yang dilaunching bulan Agustus 2015, merupakan upaya untuk mengangkat citra kota Malang sebagai kota wisata. Slogan Beautiful Malang merupakan upaya menjual (marketing) keindahan kota Malang, untuk meningkatkan kunjungan wisata kota Malang.
Keindahan fisik (physical beauty) kota merupakan kondisi, karakter, cita (image) yang terbentuk dari setting lingkungan binaan (elemen rancang kota) bersama lingkungan alamiahnya. Sehingga upaya membuat City Branding dengan mengangkat tema Beautiful Malang menjadi relevan apabila diikuti dengan upaya-upaya pemerintah kota untuk menjaga "keindahan lingkungan buatan dan alamiahnya" dalam kebijakan pengembangan kota Malang.

Pembahasan tentang persepsi keindahan suatu kawasan dan/atau kota tidak terlepas dari permasalahan image dari pengguna (stakehokders) kota. Sehinga ketika kita akan mengupas beautiful Malang sebagai branding, maka tidak akan terlepas dari pemahaman Image suatu kota/ kawasan. Menurut Kevin Lynch (1960), pemahaman image sebuah kota mencakup 5 elemen, yakni Path, Edge, District, Nodes, dan Landmark. Hal ini bermakna bahwa upaya menciptakan image dengan branding "beautiful Malang" harus mencakup 5 elemen tersebut sebagai upaya kongkrit mengangkat keindahan atau image kota Malang. Permasalahan yang diangkat dalam tulisan ini adalah adakah keterkaitan City Branding Beautiful Malang terhadap dampak peningkatan image/citra Kota Malang. Tulisan ini bertujuan mengkaji City Branding Beautiful Malang ditinjau dari teori Citra kota (Lynch, 1960). Kesimpulan pembahasan ini diharapkan dapat memberi masukan bagi pemerintah dan masyarakat Kota Malang. 


\section{STUDI LITERATUR}

\section{City Branding}

Upaya peningkatan citra kota dalam perspektif pencitraan atau branding kota, banyak kota berupaya untuk mempromosikan diri melalui pembangunan elemen-elemen fisk kota untuk menghadirkan artefak ikonik (Wikantiyoso, 2005). Upaya mewujudkan City Branding (World Health Organization, 2017) terutama didasarkan pada tiga atribut utama yang harus dipenuhi yaitu citra (Image), keunikan (identity) dan keaslian (Originality). Hampir semua kota di Indonesia mencoba untuk memiliki jatidiri atau identitas kotanya dalam untuk mengembangkan kembali citranya (Wikantiyoso, 2007). Branding utamanya dikembangkan dari strategi pemasaran. Kota mirip dengan produk sebagaimana halnya yang digunakan untuk pemasaran dan promosi. Kota adalah place yang bisa menjadi produk, dimana identitas dan nilainya harus dirancang dan dipasarkan sebagai produk (Kotler \& Gertner, 2002).

Menurut Ashworth \& Voogd (1990), tujuan city atau place branding adalah untuk menemukan atau menciptakan keunikan, yang membuat kota dapat dibedakan dari yang lain. Tujuan utama dalam City Branding adalah menciptakan artikulasi kota di dunia global. Artikulasi tersebut membutuhkan kekayaan ekonomis dan citra yang menarik, baik dari sisi fisik, social, budaya dan lingkungan alamiahnya. Oleh karenanya pencitraan kota harus memperhatikan keseluruhan konteks dan konteks keseluruhan perkembangan Kota, sehingga dapat terwujudkan identitas yang mewakili dan dapat diterima oleh semua stakeholders kota.
City Branding adalah sebuah pendekatan holistik yang dapat berfungsi sebagai alat promosi untuk menciptakan citra kota yang unik. Dengan demikian, citra kota dapat menjadi fokus perhatian utama yang paling penting baik untuk identitas kota maupun pencitraan kota. Sebagai sebuah pendekatan holistik, (Derek, Johnston, \& Pratt, 2009) bahkan menyatakan bahwa City Branding dapat memberikan pengaruh pada kualitas hidup, karena selain faktor ekonomi dan sosial, juga sangat terkait dengan masalah lingkungan binaan.

Penetapan City Branding menjadi penting untuk memberikan arah kebijakan pengembangan kota oleh pemerintah kota. City Branding menjadi diskusi yang menarik yang dapat melibatkan akademisi, swasta, tokoh masyarakat derta pemerintah kota, untuk menetapkan strategi pengembangan dalam meningkatkan image kota. Sebagai kota bersaing secara global untuk menarik pariwisata, investasi, serta untuk menetapkan konsep strategis commercial branding kota yang tetap berbasis pada keunikan local (Wikantiyoso \& Tutuko, 2014). Peningkatan daya saing global kota yang berbasis lokalitas dengan mengadopsi pendekatan ekonomi (pemasaran) melalui City Branding dari luar dan diterapkan dalam mengejar pembangunan perkotaan, regenerasi dan kualitas hidup kota yang lebih baik.

Salah satu bentuk pemasaran kota yang sedang berkembang saat ini adalah pemberian citra kota atau City Branding (Kieith, 2011), yang sementara ini digunakan sebagai pendekatan untuk mempromosikan suatu kota. Posisi kota dengan potensi wisatanya dalam kancah pasar global, dapat dipandang sebagai sebuah produk atau sebuah perusahaan yang bersaing secara global (Murfianti, 2010). 


\section{Peran Arsitektur Ikonik}

Masyarakat modern perkotaan saat ini menggunakan bangunan ikonik untuk dikagumi dalam rangka mengembangkan eksistensi kota mereka di dunia global. Arsitektur kota merupakan akumulasi fisik elemen binaan baik dalam bentuk bangunan gedung maupun element rancang kota lainnya (Hamid, 1985). Gaya bangunan (style), tipology, serta karakter spesifiknya yang ikonik dapat menghadirkan ciri atau identitas sebagai media berkomunikasi, maupun simbol kota yang menjadi daya tarik masyarakatnya. Oleh karenanya elemen fisik kota yang ikonik dan menarik secara visual dapat mengangkat citra kota. Contoh-contoh di berbagai kota besar di dunia telah membuktikannya sebagai alat komunikasi efektif. Sebuah penelitian membuktikan 'Rumah Menari' dirancang oleh Frank O'Ghery, dan Louvre Pyramid I. M. Pei memiliki dampak positif pada kualitas hidup karena sesuai dengan konteks yang ada. Di sisi lain bangunan ikonik juga dapat memberikan dampak negatif sebagaimana dicontohkan Museum Guggenheim di Bilbao yang mengabaikan konteks yang ada dan mengurangi nilai lingkungan sekitarnya. Demikian pula, gedung Kantor Re Swiss yang tidak mempertimbangkan konteks atau lokasi yang ada. Elemen ikonik yang tidak berkontribusi terhadap citra kota salah satunya disebabkan oleh ketidakpekaan terhadap konteks kota. Elemen bangunan atau arsitektur yang ikonik adalah bagian dari kota kontemporer beserta citra dan identitasnya. Oleh karena itu untuk menciptakan dan mempertahankan identitas, bangunan harus dirancang dengan pertimbangan harmoni kontekstual, mewakili dan menghormati karakter tempat itu.

\section{Pelajaran Citra Kota Lynch bagi Upaya Pemasaran Kota}

Lebih dari setengah abad yang lalu, Kevin Lynch (1960) menggagas tentang citra kota sebagai pendekatan dan cara masyarakat melihat lingkungan perkotaan. The Image of the City (TIoTC) telah menjadi acuan klasik perencana kota yang masih sangat relevan. Dalam tulisan ini kami menganggap kerangka kerja Lynch (Stevens, 2006) untuk menilai daerah perkotaan sangat berguna untuk kota-kota yang mencari citra khas untuk memasarkan diri. Beberapa penelitian menggunakannya untuk mengeksplorasi peluang kerangka kerja untuk pemasaran kota. Penelitian lainnya mengembangkan kerangka kerja Lynch (Al-Kodmany, 2001; Hu \& Chen, 2018; Stevens, 2006) untuk memeriksa hubungan antara lingkungan yang dibangun kota dan pemasaran kota.

Kota-kota saat ini menjadi lebih peduli dari sebelumnya terhadap identitas, citra dan nilai merek mereka. Di era teknologi informasi digital saat ini kota semakin pandai memposisikan diri terhadap kota lainnya. Kota menjadi semakin menyadari bahwa dalam persaingan untuk penduduk, pengusaha, pelajar dan pengunjung, tidaklah cukup untuk berinvestasi dalam infrastruktur, fasilitas budaya, dan fasilitas lainnya. Persaingan tersebut terlihat dalam kegiatankegiatan pencitraan kota. Citra tempat yang buruk dapat menurunkan nilai daya tariknya dan lebih lanjut 
berdampak pada kinerja ekonomi lokalnya dalam jangka panjang. Oleh karena itu, seluruh stakeholder perkotaan mulai memikirkan kembali apa yang dapat ditawarkan kota mereka (identitas) serta bagaimana kota mereka dipersepsikan oleh masyarakat luas, dan berikutnya adalah bagaimana perbedaan antara keduanya harus diatasi. Salah satunya adalah dengan place marketing yang mampu menunjukkan nilai itu melalui investasi di kota, program atraksi, dan instrumen komunikatif (Kjartansdóttir, 2014; Toolis, 2017).

TIoTC menawarkan wawasan yang berguna bagi pemasaran kota. Jika benar, seperti yang dikemukakan Lynch, bahwa lima elemen visual dalam lingkungan binaan memengaruhi persepsi kita terhadap kota, maka kota harus lebih memanfaatkan hal itu dalam pengembangan strategi pemasaran tempat mereka. Pemasaran kota dapat belajar dari Lynch bahwa mereka harus lebih peduli tentang kemungkinan "imageability" dari kota mereka. (Al-Kodmany, 2001; Anholt, 2007; Ashworth \& Voogd, 1990; Jansson \& Power, 2006)

\section{METODE PENELITIAN}

Tulisan ini didukung riset sederhana dengan menggunakan data hasil observasi terhadap sejumlah elemen kota di Kota Malang menurut kinerja Lynch (Hu \& Chen, 2018; Stevens, 2006). Penelitian dilakukan dengan metode dan analisis deskriptif kualitatif.

\section{HASIL DAN PEMBAHASAN}

\section{Eksplorasi Citra Kota Malang}

Beautiful Malang adalah upaya penciptaan City Branding maka pemerintah Kota Malang. Gagasan slogan Beautiful Malang sebagai City Branding Kota Malang, dilatar belakangi oleh potensi alamiah kota, pemandangan alam, hawa yang sejuk, teduh dan asri serta keberadaan bagunan bangunan peninggalan Belanda.

Menurut sejarah Kota Malang yang dirancang pemeritahan Belanda sebagai kota peristirahatan. Bebarapa kota yang memeiliki potensi alamiah yang sejuk seperti kota Malang. oleh pemerintah Belanda digunakan sebagai kota2 untuk peristiharatan dan rekreasi. Kondisi geografis kota Malang yang berada didataran tinggi dan berada di lingkung gunung menjadi daerah yang ideal untuk kota tempat tinggal (peristirahatan). Kondisi lingkungan alam yang sangat baik menjadikan Kotapraja Malang sangat ideal untuk menjadi daerah tujuan wisata. Melalui perencanaan kota yang baik dengan ditetapkannya Bouplan I sampai dengan Bouplan VIII, maka kota Malang menjadi salah satu kota yang dibangun dengan menggunakan konsep Garden City Pada masa kolonial Belanda (Wikantiyoso, 2005). Sebagai sebuah kota tujuan wisata maka dibangun beberapa hotel, dan fasilitas perbelanjaan (Kajoetangan).

\section{Implementasi Tatanan Fisik dan Visualisasi Ikonik pada Elemen Citra Kota .}

Dalam upaya mewujudkan City Branding Beautiful Malang harus terus dilakukan upaya pendekatan yang komprehensif, dan berkelanjutan. Dengan demikan sebenarnya implementasi City Branding menuntut proses 
pembangunan yang berkelanjutan (sustainable development), yang mencakup aspek pengembangan fisik, sosial-budaya, lingkungan, dan ekonomi. Pembahasan Image kota tidak terlepas dari 5 element fisik kota sebagaimana diuraikan oleh Kevin Lynch (1960). Artikel ini hanya membahas tentang Citra Kota (Image) dalam Beautiful Malang City Branding. Analisis image kota dengan menggunakan kerangka teori TIoTC (Lynch, 1960).

Upaya penataan fisik kota difokuskan pada kelima elemen citra kota: yaitu

1. Path atau jalur jalan (pathway); merupakan fasilitas prasarana mobilitas penduduk kota bisa berupa jalur jalan, pedestrian ways, trottoir yang merupakan fasilitas public memanjang menghubungkan satu fasilitas ke fasilitas lainnya. Path/pathways karakter dan tipologinya ditentukan oleh fungsi, bentuk (lebar dan material), serta disainnya. Pathways berbentuk jalan memiliki tipologi sesuai dengan Peraturan Pemerintah Republik Indonesia Nomor 34 Tahun 2006 Tentang Jalan. Prasarana jalan digunakan untuk mobilitas penduduk kota dalam menjalankan kegiatan kesehariannya.

Bentuk lain Path adalah jalur pedestrian merupakan jalur yang dibangun secara khusus untuk pejalan kaki. Dengan fungsi yang sama trottoir masuk dalam kategori pedestrian ways, walaupun dengan tipologi yang berbesa. Trotoir biadanya terletak disepanjang sisi kiri dan/atau kanan jalur jalan, sedangkan jalur pedestrian dapat berupa falilitas laluan pejalan kaki yang terpisah dengan jalur jalan. Path biasanya dilengkapi dengan kelengkapan fasilitas pedestrian dalam bentuk street furniture berupa tempat duduk/bangku, tempat sampah, lampu taman, dan beberapa taman yang memanjang sepanjang jalur pedestrian. Disain kelengkapan path tersebut akan memperkuat kesan corridor taman kota.

Pemerintah kota Malang beberapa tahun terakhir sudah berupaya untuk melakukan revitalisasi Jalur pedestrian dengan memanfaatkan program CSR beberapa perusahaan swasta di Malang (Juwito, Wikantiyoso, \& Tutuko, 2019). Upaya yang sudah dilakukan pemerintah Kota Malang memberi tanaman dan pot bunga serta kursi taman di sepanjang koridor Utama Jl Ahmad Yani sampai Basuki Rahmat serta Jalan Kawi sampai Ijen.

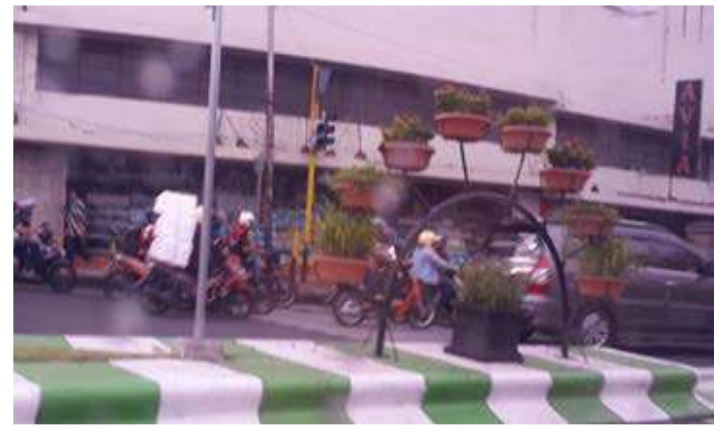

Gambar 1. Tatanan fisik di koridor utama Utama Jl Ahmad Yani sampai Basuki Rahmat serta Jalan Kawi sampai Ijen (sumber: foto Pribadi, 2017)

Upaya lainnya adalah membuat Taman Kota di beberapa RTH Aktif di Kota Malang

1. Taman Alun Alun Merdeka. Taman Alun-Alun Merdeka saat ini menjadi lebih sejuk karena 
ditambah rerumputan hijau yang bisa dijadikan tempat untuk duduk-duduk santai sambil berteduh. Selain itu ada fasilitas berupa jogging track, skatepark untuk bermain skateboard, taman bermain, bikers track, bangku taman, smoking area, tempat khusus ibu menyusui, , toilet yang lebih bersih, serta jalur difabel.

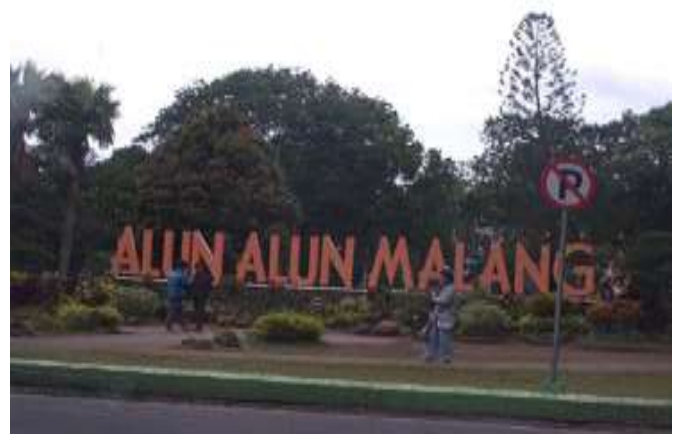

Gambar 2. Taman Alun Alun Merdeka, (Yosaf, 2017)

2. Taman Alun-alun Tugu dan Taman Trunojoyo Taman Tugu terletak di depan Balai Kota Malang, dan Taman Trunojoyo di depan Stasiun Kota Baru.

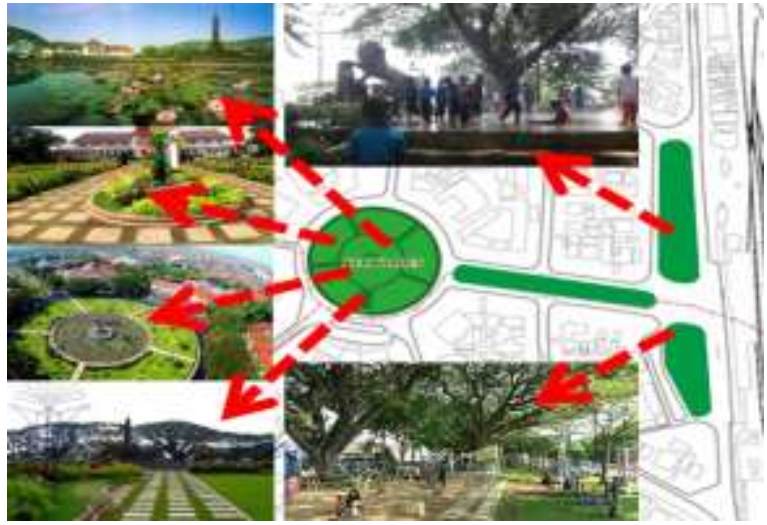

Gambar 3. Taman Alun-alun Tugu, (Wikantiyoso 2018)

3. Taman Dempo yang merupakan CSR, diolah dengan fasilitas Joging Track (path).

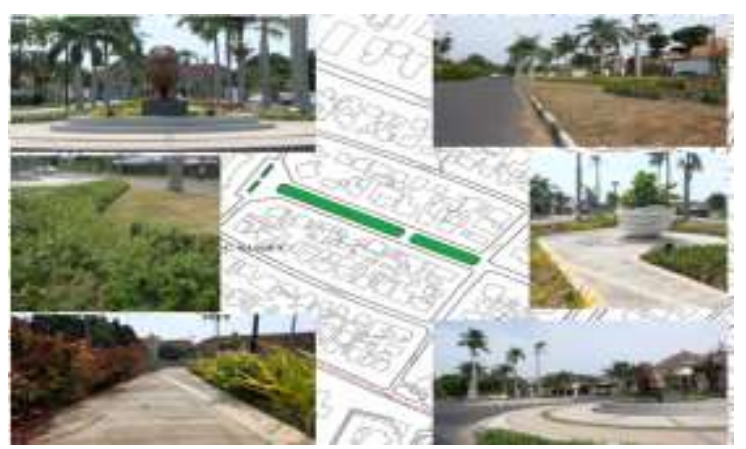

Gambar 4: Taman Dempo, (Wikantiyoso 2018)

4. Taman Merbabu Taman ini menyediakan area bermain dan olahraga, seperti futsal dan fitness outdoor. 


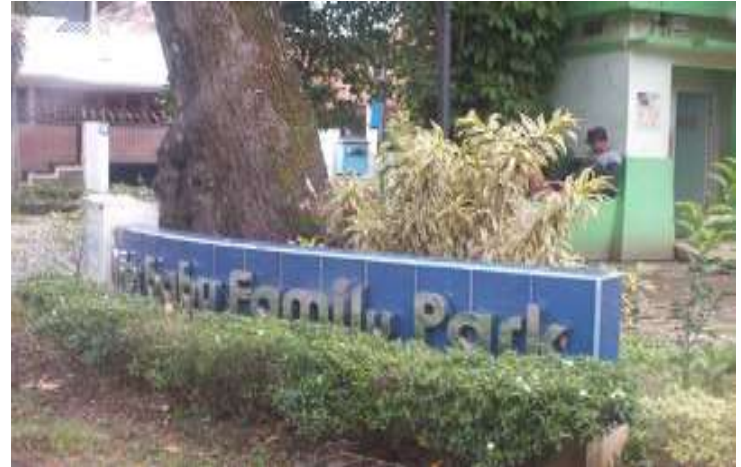

Gambar 5. Taman Merbabu, (Yosaf, 2017)

5. Taman Cidurian Pasca penataan substitusi material porous paving stone, untuk public space dan resapan air hujan. Sebagai taman lingkungan, Taman Cidurian dilengkapai fasilitas Joging track dan menambah citra/image lingkungan hunian menjadi lebih positif.

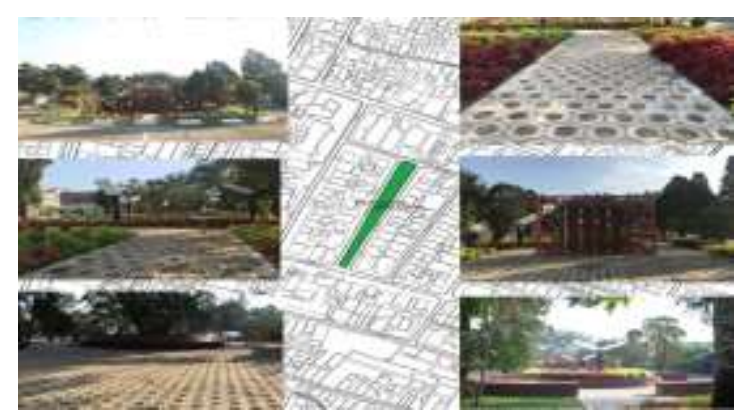

Gambar 5: Taman Cidurian, (Wikantiyoso 2018)
6. Taman Ken Dedes, sebagai taman Icon Masuk pintu kota Malang

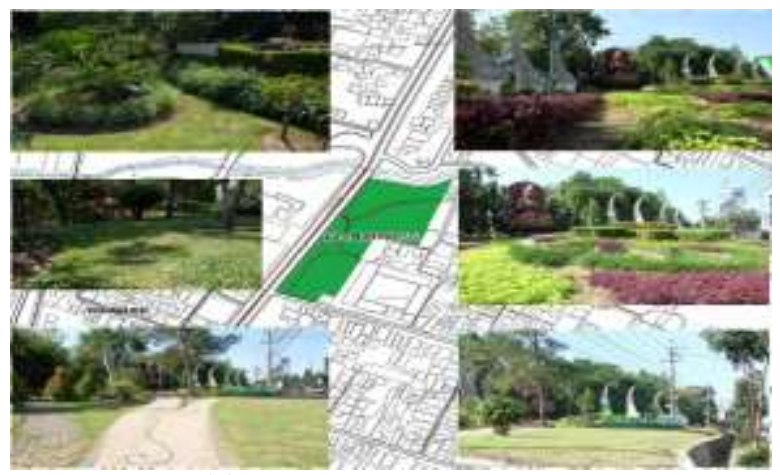

Gambar 6: Taman Ken Dedes, (Wikantiyoso, 2018)

Penataan Taman Ken Dedes, sebagai taman Icon Masuk pintu kota Malang, dan lebih berfungsi sebagai taman estetika dan penunjang ekologi kota, dengan akses public yang minimal, terjadi perubahan ruang terbuka (soft space) menjadi ruang aktifitas (bard public space). Keberadaan perkerasan hanya dilakukan untuk kemudahan akses (path way) dengan material paving stone, dan perkerasan rabat beton.

7. Taman Idjen Boulevard 


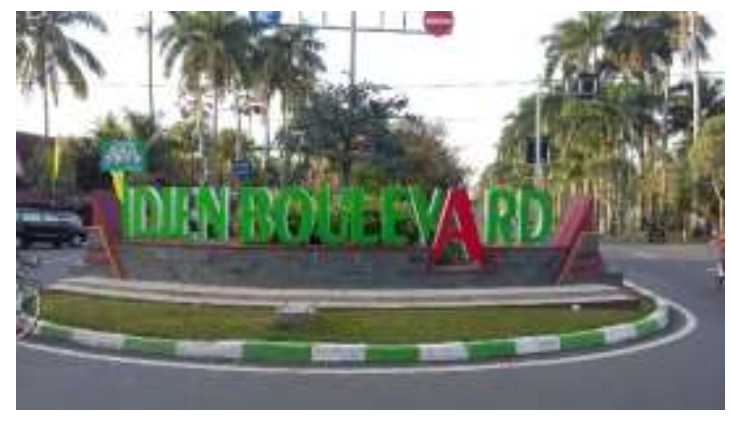

Gambar 7. Idjen Boulevard, (Yosaf, 2017)

8. Taman Slamet Terletak di jalan taman slamet terdapat area selfie, tempat duduk, tempat olahraga jogging track.

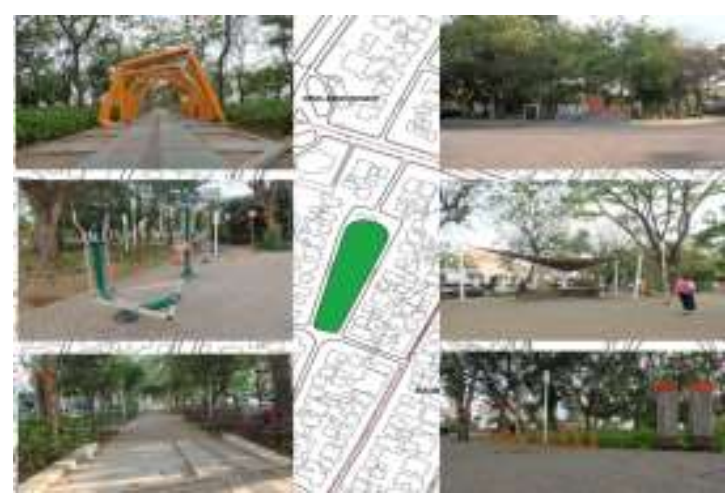

Gambar 8. Taman Slamet, (Wikantiyoso, 2018)
2. Edges/Tepian: elemen fisik alamiah dan/atau buatan yang berbentuk liniear, yang dapat berfungsi sebagai pembatas tepian/penghalang, atau sebagai jalur pedestrian yang memisahkan satu bagian kota dengan lainnya. Edges dapat berbentuk koridor pedestrian ways, koridor hijau kota dan sebagainya. Kota Malang yang dilintasi 5 Sungai sebenarnya sangat potensial untuk diolah membentuk elemen edges disepanjang jalur sungai. Dalam Master plan RTH Kota Malang 20122023 telah ditetapkan sepanjang tepian sungai dijadikan green belt atau jalur hijau. Penetapan Master Plan RTH oleh pemerintah kota Malang merupakan salah satu upaya untuk memperjelas posisi Edges kota khususnya penetapan greenbelt di sepanjang aliran sungai.

Penataan kawasan bantaran sungai menjadi kampung wisata, seperti kampung Warna-Warni (gambar 9), perlu dilakukan revitalisasi khususnya pada daerah "batas" antara badan sungai dengan permukiman penduduk.

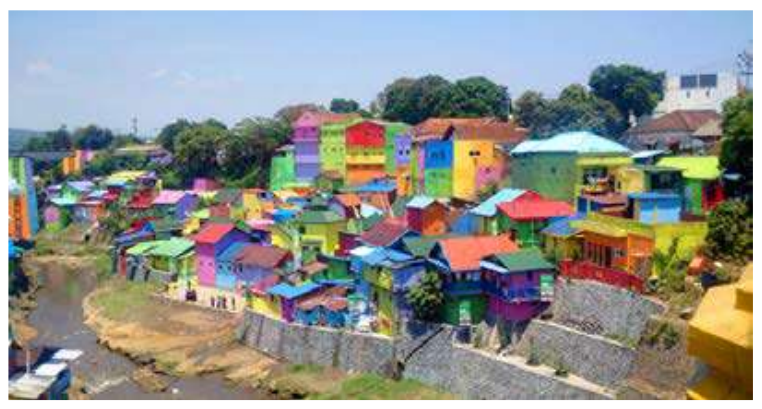

Gambar 9. kampung Warna Warni Kelurahan Jodipan.(sumber: foto pribadi, 2017) 
3. District; Kawasan atau bagian Kawasan kota yang memiliki karakteristik dan atau dominasi khusus baik secara fisik maupun non fisik (activity) dapat dimasukkan dalam kategori District. Dominasi karekter fisik yang dimaksud adalah adanya pola dan atau bentukan lingkungan fisik (buatan dan alamiah) yang dengan jelas dapat dibedakan dengan kawasan lainnya. Dominasi merupakan suatu bagian kota mempunyai karakter atau aktivitas khusus yang dapat dikenali oleh pengamatnya. District memiliki bentuk pola dan wujud yang khas begitu juga pada batas district sehingga terlihat mana batas akhir atau awal kawasan tersebut.

Dengan demikian secara fisik district memiliki ciri dan karakteristik kawasan yang berbeda dengan kawasan disekitarnya. District juga mempunyai identitas yang lebih baik jika batasnya dibentuk dengan jelas tampilannya dan dapat dilihat homogen, serta fungsi dan komposisinya jelas. Upaya yang dilakukan pemkot Malang membuat sebuah kampung wisata di setiap kelurahan- kelurahan di Kota Malang sehingga bisa mengekspos potensi masing masing kelurahan di Kota Malang. Contoh kampung Glintung Go Green (kampung 3G) mendapat nominasi nominasi 15 besar Guangzhou International Award for Urban Innovation.

4. Nodes/ simpul: Kehidupan kota yang sangat dinamis, dengan penduduk yang sangat heterogen akan menghadirkan karakter aktifitas yang spesifik pada setiap simpul Kawasan kota. Kegiatan-kegiatan spesifik kota dengan berbagai potensinya akan menghadirkan "enclave" atau simpul-simpul aktifitas kota. Pengembangan kampung-kampung thematic serta dominasi aktifitas pada Kawasan tertentu, seperti Kawasan Pasar Besar, Comboran, Kawasan Pecinan, Kawasan Alun-alun Merdeka dan lain-lain, merupakan contoh kongkret keberadaan nodes. Nodes kota dapat berbentuk Kawasan atau simpul strategis dengan karakter aktivitas yang menonjol dan berbeda antara satu nodes dengan nodes lainnya. Dengan demikian Node akan memiliki mempunyai identitas jika tempatnya memiliki karakter, pola, serta bentuk yang dominan dan mudah diingat, serta sangat spesifik dan uniq berbesa dengan Kawasan lainnya.

Pengembangan kota Malang dengan enam Satuan Wilayah Pengembangan (SWP) telah ditetapkan pusat-pusat wilayah pengembangan sebagaimana diilustrasikan pada gambar 10. 


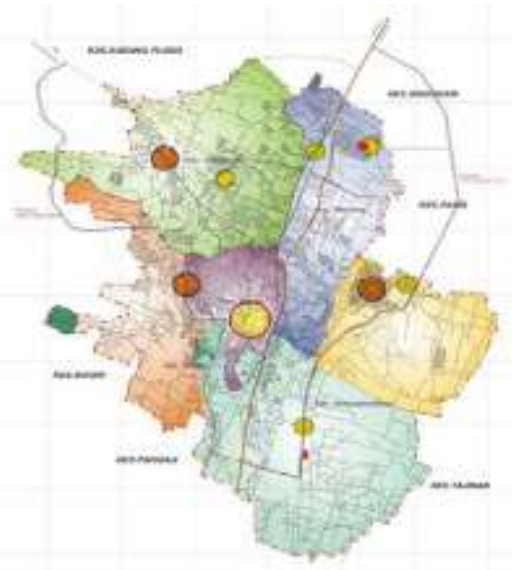

Gambar 10. Simpul-simpul Satuan Pusat Wilayah Pengembangan Kota Malang. (RTRW kota Malang 2010-2030)

5. Landmarks/Tengaran; Eksistensi Landmark sebuah kota menduduki peran yang sangat penting. Jika mengacu pada elemen perancangan kota Hamid Sirvani (1985), keberadaan landmark merupakan salah satu elemen signage atau penanda kota. Sebagai elemen perancangan kota yang berfungsi sebagai penenda kota, landmark menjadi sangat penting dari sisi disain (bentuk, skala, posisi, warna, bahkan simbolisasi). Sebuah kandmark dalam berupa bangunan Gedung dan/atau bukan bangunan Gedung yang memiliki disain yang menonjol, spesifik, unik, serta memiliki skala monumental (minimal berbeda dengan lingkungan sekitarnya).
Ditinjau dari sisi disain (bentuk, skala, posisi, warna, bahkan simbolisasi) serta fungsinya sebagai penanda, landmark harus terlihat dominan, menonjol serta menarik secara visual dengan posisi penempatan yang strategis. Biasanya landmark mempunyai bentuk yang unik serta terdapat perbedaan skala dalam lingkungannya. Beberapa landmark hanya mempunyai arti di daerah kecil dan hanya dapat dilihat di daerah itu, sedangkan landmark lain mempunyai arti untuk keseluruhan kota dan bisa di lihat dari manamana. Landmark adalah elemen penting dari bentuk kota karena membantu orang mengenali suatu daerah. Selain itu landmark bisa juga merupakan titik yang menjadi ciri dari suatu kawasan. Beberapa tempat yang menjadi landmark Kota Malang yaitu (1) Patung Kendedes Arjosari, (2) Tugu Alun Alun depan balaikota, (3) Alun Alun Merdeka dan (4) Idjen Boulevard

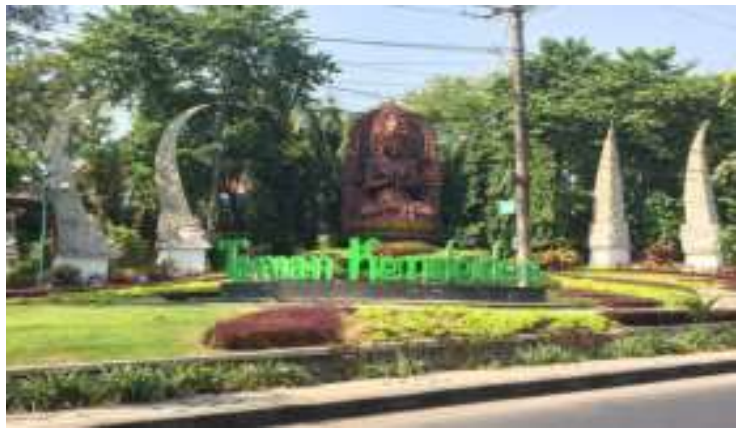

Gambar 11. Patung di Taman Kendedes Malang 


\section{KESIMPULAN}

Beberapa catatan kecil yang dapat dirangkum dari hasil pengamatan, kajian teori dan data serta pembahasan, yakni:

1. Pengembangan kota dapat menggunakan City Branding sebagai kerangka acuan dalam menentapkan tujuan, visi serta misi pengembangannya.

2. Kerangka teori Kevin Lynch (1960), tentang TIoTC dapat menjadi kerangka acuan kerja dalam membaca, menggambarkan bahkan dalam merancang dan/atau membentuk Image kota Malang.

3. City Branding Beautiful Malang yang dicanangkan Pemerintah Kota Malang sudah menghasilkan dampak positif bagi kemajuan Kota Malang. Hal ini juga dibuktikan dari beberapa penghargaan yang diraih Kota Malang. Di antaranya penghargaan sebagai kota dengan Taman Terbaik tingkat Nasional. sehingga hal ini berdampak menarik kunjungan wisata ke Kota Malang.

\section{REFERENSI}

Al-Kodmany, K. (2001). Supporting imageability on the World Wide Web: Lynch's five elements of the city in community planning. Environment and Planning B: Planning and Design, 28(6), 805-832. https://doi.org/10.1068/b2746t

Anholt, S. (2007). Competitive Identity: The New Brand Management for Nations, Cities and Regions. New York: Palgrave.
Ashworth, G., \& Voogd, H. (1990). Selling the City: Marketing Approaches in Public Sector Urban Planning. London: Belhaven Press.

Derek, G., Johnston, R., \& Pratt, G. (2009). Quality of Life. Dictionary of Human Geography (5th ed.). Oxford, UK: Wiley- Blackwell.

Hamid, S. (1985). Urban Design Process (illustrate). Calofornia: Van Nostrand Reinhold.

Hu, M., \& Chen, R. (2018). A Framework for Understanding Sense of Place in an Urban Design Context. Urban Science, 2(2), 34. https://doi.org/10.3390/urbansci2020034

Jansson, J., \& Power, D. (2006). Image of the City: Urban Branding as Constructed Capabilities in Nordic City Regions, Research Report. Oslo: Nordic Innovation Centre.

Juwito, J., Wikantiyoso, R., \& Tutuko, P. (2019). Kajian Persentase Ruang Terbuka Hijau pada Implementasi Revitalisasi Taman Kota Malang (Study of Percentage of Green Open Space in the Implementation of Malang City Park Revitalization). Local Wisdom : Jurnal Ilmiah Kajian Kearifan Lokal. https://doi.org/10.26905/lw.v11i1.2686

Kieith, D. (2011). City Branding: Theory and Cases. London: Palgrave Macmilan.

Kjartansdóttir, T. K. (2014). Theories of place making and local development planning. 1-25.

Kotler, P., \& Gertner, D. (2002). Country as a brand, product and beyond: A place marketing and brand management perspective. Journal of Brand Management, 9(4-5).

Lynch, K. (1960). Image of The City. Cambridge: MIT Press.

Murfianti, F. (2010). Membangun City Branding Melalui Solo Batik Carnival. Penelitian Seni Dan Budaya, 2(1). 
Stevens, Q. (2006). The shape of urban experience: A reevaluation of Lynch's five elements. Environment and Planning B: Planning and Design, 33(6), 803-823. https://doi.org/10.1068/b32043

Toolis, E. E. (2017). Theorizing Critical Placemaking as a Tool for Reclaiming Public Space. American Journal of Community Psychology, 59(1-2), 184-199. https://doi.org/10.1002/ajcp.12118

Wikantiyoso, R. (2005). Paradigma Perencanaan dan Perancangan Kota (2nd ed.). Malang: Grup Konservasi Arsitektur dan Kota.

Wikantiyoso, Respati. (2005). Ulasan Disain Urban Kawasan Idjen Boulevard (2nd ed.). Malang: Grup Konservasi Arsitektur dan Kota.

Wikantiyoso, Respati. (2007). Perencanaan dan Perancangan Kota Sebagai Penduan Pengembangan Kota (Antara Idealisme dan Ketaatan Implementasinya) D.

Wikantiyoso, Respati, \& Tutuko, P. (2014). Editorial introduction: Special Issue on Local Wisdom for Better City Planning. International Review for Spatial Planning and Sustainable Development, 2(4). DOI: http://dx.doi.org/10.14246/irspsd.2.4_1 (18)

World Health Organization. (2017). Urban green spaces: a brief for action. 24. Retrieved from http://www.euro.who.int/_data/assets/pdf_fil e/0010/342289/Urban-Green-

Spaces_EN_WHO_web.pdf?ua $=1$ 